\title{
UPAYA MENINGKATKAN AKTIVITAS DAN HASIL BELAJAR MATEMATIKA MENGGUNAKAN MEDIA CD PEMBELAJARAN DISERTAI PEMBERIAN TUGAS PADA SISWA KELAS VII SMP NEGERI 1 BANJAR MARGO
}

\author{
SUMBOGO B. M. \\ SMP Negeri 1 Banjar Margo \\ sumbogobm66@gmail.com
}

\begin{abstract}
This research is a class action (classroom action research). The aims this research is to determine whether the use of $C D$ learning about triangles and rectangles can increase the activity of students and student learning outcomes class VII.7 SMP Negeri 1 Banjar Margo in the academic year 2015/2016. Based on the analysis, obtained an average student activity before the action amounted to $42.53 \%$, the average student activity first cycle of $65.33 \%$ and the average student activity cycle II 74.00\%. Means the average activity of students has increased by $15.7 \%$. The average results of student learning the first cycle of 56.7 and an average student learning outcomes cycle II of 65.3, an average of learning outcomes increased by $15.2 \%$. Before remedial many students who pass the study in the first cycle of 16 students (53.3\%), it increased 5 students (16.7\%) from the prior action. And the second cycle students who pass the study were 21 students (70.0\%), it increased 5 students (16.7\%) of the cycle I. Based on the results of classroom action research conducted and the discussions that have been described, it can be concluded that the use of CD Lesson in Math learning materials triangles and rectangles can increase the activity and student learning outcomes VII.1 grade SMPN 1 Banjar Margo, Tulang Bawang in the academic year 2015/2016.
\end{abstract}

Keywords: Classroom Action Research, Student Learning Outcomes, Activity, Application of CD Media Learning With Task

\section{PENDAHULUAN}

Pembelajaran merupakan suatu proses yang sangat komplek, banyak faktor yang mempengaruhi jalannya proses pembelajaran tersebut. Faktorfaktor yang mempengaruhi jalannya proses pembelajaran matematika di sekolah diantaranya adalah faktor guru, siswa, metode pembelajaran, buku pelajaran, alat pembelajaran, lingkungan keluarga, lingkungan sekolah maupun pemerintah. Keberhasilan suatu pembelajaran tidak dapat tercapai begitu saja, tanpa adanya aktivitas belajar dari siswa tersebut, maka suatu pembelajaran tidak akan berhasil. Aktivitas belajar merupakan proses dalam mencapai hasil belajar. Sardiman (2007:95) menyatakan bahwa sebab pada prinsipnya belajar adalah berbuat untuk merubah tingkah laku.
Tidak ada belajar jika tidak ada aktivitas, itulah sebabnya aktivitas merupakan prinsip atau azas yang sangat penting dalam interaksi belajar mengajar.

Aktivitas belajar adalah kegiatan siswa dalam berinteraksi pada proses belajar mengajar yang mengakibatkan perubahan pada dirinya. Sardiman (2007:95) aktivitas yang melibatkan fisik maupun mental dapat dibedakan menjadi delapan jenis yaitu :

1. Visual activities misalnya : membaca memperhatikan pelajaran, memperhatikan gambar, demonstrasi, percobaan, dan memperhatikan pekerjaan orang lain.

2. Oral activites Misalnya : menyatakan, merumuskan, 
bertanya, memberi saran, mengeluarkan pendapat, wawancara, diskusi dan interupsi.

3. Listening activities misalnya : mendengarkan uraian, percakapan, diskusi, musik, dan pidato.

4. Writing activities misalnya : menulis cerita, karangan laporan, angket dan menyalin.

5. Drawing activities misalnya: menggambar, membuat peta, membuat grafik, dan membuat diagram.

6. Motor activities misalnya : melakukan percobaan, membuat kerangka model, mereparasi, bermain, berkebun, dan beternak.

7. Mental activities misalnya : menanggapi, memngingat, mengerjakan soal, menganalisa, melihat hubungan, dan mengambil keputusan.

8. Emotional activities misalnya : menaruh minat, merasa bosan, gembira, bersemangat, bergairah, bermain, tenang dan gugup.

Hamalik

(2003:175-176)

menyatakan manfaat lain dalam meningkatkan aktivitas belajar siswa yaitu :

1. Para siswa mencari pengalamannya sendiri dan mengalami sendiri

2. Berbuat sendiri akan mengembangkan seluruh aspek pribadi menjadi demokrasi

3. Memupuk disiplin kelas secara wajar dan suasana belajar menjadi demokrasi
4. Para siswa belajar menurut minat dan kemampuan sendiri

5. Mempererat hubungan sekolah dan masyarakat dan hubungan antara orang tua dengan guru

6. Pengajaran diselenggarakan secara realistis dan konkrit sehingga mengembangkan pemahaman dan berfikir kritis

7. Pengajaran di sekolah menjadi hidup sebagaimana aktivitas dalam kehidupan masyarakat

8. Memupuk kerja sama yang harmonis di kalangan siswa

Dalam proses belajar mengajar, kehadiran media mempunyai arti yang cukup penting, karena dalam kegiatan belajar mengajar ketidak jelasan bahan yang disampaikan dapat diatasi dengan bantuan media pembelajaran sebagai perantara. media $\mathrm{CD}$ pembelajaran adalah suatu lingkungan tiruan dalam wujud audio visual yang digunakan dalam pembelajaran untuk merangsang pikiran siswa sehingga tercipta suatu proses pembelajaran yang baik. Menurut Sanjaya (2008:221-222): CD interaktif dapat digunakan pada berbagai jenjang pendidikan dan berbagai bidang studi. Sifat media ini selain interaktif juga bersifat multi media terdapat unsur-unsur media secara lengkap yang meliputi sound, animasi, video, teks, dan grafis. Pada umumnya, tipe penyajian yang banyak digunakan adalah tutorial dalam bentuk CD interaktif. Model ini membimbing siswa secara tuntas untuk menguasai materi dengan cepat dan menarik. Kelebihan lain dari CD interaktif ini adalah siswa dapat belajar secara mandiri, tidak harus tergantung kepada guru/instruktur. Siswa dapat memulai belajar kapan saja dan dapat mengakhiri 
sesuai dengan keinginannya. Selain itu, materi-materi yang diajarkan dalam $\mathrm{CD}$ tersebut dapat langsung dipraktikkan oleh siswa. Terdapat juga fungsi repeat, bermanfaat untuk mengulangi materi secara berulang-ulang untuk penguasaan secara menyeluruh. Ahmadi (2001:21) mengemukakan bahwa suatu hasil belajar yang dicapai dalam suatu usaha belajar dalam hal ini adalah mewujudkan nilai dan prestasi belajar siswa yang dapat dilihat pada hasil atau nilai dan prestasi belajar siswa yang diperoleh dalam setiap mengikuti tes.

Selama ini proses pembelajaran yang dilakukan guru di SMP Negeri 1 Banjar Margo, Kabupaten Tulang
Bawang pada umumnya belum dapat berjalan sesuai dengan tuntutan kurikulum. Menurut pengakuan beberapa guru yang mengajar di SMP Negeri 1 Banjar Margo mereka hanya menggunakan metode ceramah, Tanya jawab, demonstrasi dan pemberian tugas.

Proses pembelajaran tersebut belum membuahkan hasil yang sesuai dengan yang diharapkan. Hasil belajar siswa ternyata masih rendah, hal ini dapat dilihat pada rekapitulasi hasil evaluasi mid semester kelas VII.7 SMP Negeri 1 Banjar Margo, Kabupaten Tulang Bawang semester genap tahun pelajaran 2015/2016 di bawah ini.

Tabel 1. Rekapitulasi nilai hasil evaluasi mid semester genap kelas VII.7 SMP Negeri 1 Banjar Margo Tahun Pelajaran 2015/2016

\begin{tabular}{|c|c|c|c|}
\hline Rentang Nilai & Keterangan & Persentase & Jumlah siswa \\
\hline$<60$ & Belum tuntas & $63,4 \%$ & 19 \\
\hline$\geq 60$ & Tuntas & $36,6 \%$ & 11 \\
\hline Jumlah & & $100 \%$ & 30 \\
\hline
\end{tabular}

Sumber : Buku Nilai Semester Genap Tahun Pelajaran 2015/2016

Berdasarkan rekapitulasi hasil Buku pelajaran matematika di SMP evaluasi belajar siswa di atas, dari 30 orang siswa yang tuntas belajar hanya 11 orang $(36,6 \%)$, sedangkan 19 siswa $(63,4 \%)$ belum tuntas belajar. Rendahnya hasil belajar siswa pada pembelajaran matematika kelas VII.7 SMP Negeri 1 Banjar Margo, Kabupaten Tulang Bawang mungkin karena penggunaan metode pembelajaran yang kurang cocok atau sumber belajar dan alat pembelajaran yang kurang bervariasi.

Permasalahan yang muncul di SMP Negeri 1 Banjar Margo, Kabupaten Tulang Bawang adalah hasil belajar matematika rendah, aktivitas belajar matematika juga rendah. Hal ini disebabkan oleh : (1) siswa pasif karena menerima info secara abstrak. (2) siswa merasa bosan atau enggan untuk melakukan aktivitas belajar matematika.

Negeri 1 Banjar Margo, Kabupaten Tulang Bawang sangat kurang, siswa tidak mempunyai buku pelajaran sendiri, mereka hanya menggunakan buku-buku pelajaran matematika yang ada di perpustakaan sekolah.

Oleh karena itu untuk mengatasi permasalahan di atas pada kesempatan ini kami bersama para guru di SMP Negeri 1 Banjar Margo, Kabupaten Tulang Bawang ingin mencoba melakukan proses pembelajaran dengan menggunakan CD pembelajaran tentang segitiga dan segi empat yang disertai pemberian tugas. Dengan demikian proses pembelajaran matematika akan lebih bervariasi, dan dapat menimbulkan gairah siswa untuk belajar matematika. Sehingga diharapkan aktivitas belajar matematika akan meningkat, demikian pula hasil belajar 
matematika akan meningkat pada siswa kelas VII.7 SMP Negeri 1 Banjar Margo, Kabupaten Tulang Bawang.

CD pembelajaran tentang segitiga dan segi empat ini memuat penyampaian materii pelajaran matematika dengan menunjukkan langsung kepada siswa suatu konsep, atau suatu proses yang terjadi pada segitiga dan segi empat. Dengan demikian akan sangat membantu siswa untuk mempelajari konsep tertentu dalam segitiga dan segi empat. Dalam proses pembelajaran matematika dengan menggunakan $\mathrm{CD}$ pembelajaran disertai pemberian tugas, diharapkan dapat meningkatkan aktivitas siswa dan hasil belajar siswa kelas VII.7 SMP Negeri 1 Banjar MargoPenelitan Tindakan Kelas ini bertujuan untuk mengetahui apakah penggunaan $\mathrm{CD}$ pembelajaran tentang segitiga dan segi empat dapat meningkatkan aktivitas siswa dan hasil belajar siswa kelas VII.7 SMP Negeri 1 Banjar Margo Tahun Pelajaran 2015/2016.

\section{METODE PENELITIAN}

Jenis penelitian adalah Penelitian Tindakan Kelas (PTK). Penelitian tindakan kelas dilaksanakan melalui proses tahapan seperti yang dikemukakan oleh Menurut Arikunto (2006:2) penelitian tindakan kelas adalah sebuah kegiatan penelitian yang dilakukan di kelas dengan tahapan secara umum sebagai berikut :

1. Tahapan Perencanaan

2. Tahapan Pelaksanaan

Proses belajar mengajar berlangsung 3 kali pertemuan dalam setiap siklus, waktu yang digunakan setiap pertemuan 2 x 40 menit.

3. Observasi/Pengamatan

Pengamatan aktivitas siswa dilakukan oleh empat orang guru mitra, dengan mengisi lembar observasi aktivitas siswa yang telah disediakan.

Pengamatan kegiatan guru dilakukan oleh seorang guru mitra, dengan mengisi lembar observasi kegiatan guru yang telah disediakan

4. Refleksi

Setelah data diperoleh selama proses pembelajaran siklus I, lembar observasi dianalisis untuk mengetahui kelemahan-kelemahan yang ada. Dan menentukan langkahlangkah yang perlu diperbaiki dalam proses siklus berikutnya. Pada awal siklus I permasalahan yang muncul yaitu mengubah prilaku siswa dari cara belajar yang hanya menerima informasi langsung dari gurunya ke memperhatikan tayangan CD Pembelajaran

Subyek dalam penelitian ini adalah seluruh siswa kelas VII.1 SMPN 1 Banjar Margo, Kabupaten Tulang Bawang tahun pelajaran 2015/2016 yang terdiri dari 30 siswa. Instrumen yang digunakan untuk pengambilan data hasil belajar berupa soal-soal pilihan ganda dengan empat pilihan jawaban. Pembuatan soal-soal dilakukan oleh peneliti yang disesuaikan dengan indikator yang telah ditetapkan dalam RPP, dan sebelumnya dibuat kisi-kisi soal.

\section{HASIL PENELITIAN DAN PEMBAHASAN}

Penelitian Tindakan Kelas dilaksanakan setelah persiapan penelitian yang terdiri dari lembar observasi kegiatan pembelajaran dan perangkat KBM selesai disusun. Pelaksanaan tindakan terbagi dalam dua siklus secara berkelanjutan. Jumlah subyek 30 orang siswa dan Observer 4 orang untuk mengamati aktivitas belajar siswa, 1 orang untuk mengamati kegiatan guru dalam proses pembelajaran. Pengambilan data aktivitas belajar siswa 
dilakukan 6 kali dalam 2 siklus dan pengambilan data hasil belajar siswa dilakukan 2 kali.

Dengan memperhatikan hasil observasi aktivitas belajar siswa siklus I dan siklus II didapat rata-rata persentase hasil observasi aktivitas belajar siswa sebagai

Tabel 2. Rata-rata Persentase Hasil Observasi Aktivitas Belajar Siswa Siklus I dan Siklus II

\begin{tabular}{|ll|c|c|}
\hline \multicolumn{1}{|c|}{ Aspek Yang Diamati } & Siklus I & Siklus II \\
\hline 1. & $\begin{array}{l}\text { Memusatkan perhatian pada penayangan } \\
\text { CD Pembelajaran }\end{array}$ & $78,89 \%$ & $85,56 \%$ \\
\hline $\begin{array}{l}\text { 2. } \\
\text { Menulis dan menggunakan rumus } \\
\text { matematika }\end{array}$ & $75,56 \%$ & $84,44 \%$ \\
\hline 3. & Menggambar bangun geometri & $70,00 \%$ & $76,67 \%$ \\
\hline 4. & Bertanya atau menjawab pertanyaan & $21,11 \%$ & $32,22 \%$ \\
\hline 5. & Mengerjakan soal-soal latihan & $81,11 \%$ & $91,11 \%$ \\
\hline
\end{tabular}

Berdasarkan Tabel 2. diperoleh:

1. Aktivitas belajar siswa untuk memusatkan perhatian pada penayangan CD Pembelajaran pada siklus I sebesar 78,89 \% karena ada siswa yang masih terheran-heran melihat gambar atau tulisan yang bermacam warna, atau karena siswa merasa sungkan dengan hadirnya observer ke dalam kelas tersebut, setelah penyesuaian diri aktivitas belajar siswa untuk memusatkan perhatian pada penayangan $\mathrm{CD}$ Pembelajaran pada siklus II sebesar $85,56 \%$ karena siswa sudah mulai terbiasa dengan penayangan CD Pembelajaran, berarti meningkat sebesar 6,67\%.

2. Aktivitas siswa untuk menulis dan menggunakan rumus pada siklus I sebesar 75,56 \% karena biasanya siswa hanya membaca buku, pada siklus II sebesar 84,44 karena siswa sudah mulai membiasakan diri untuk menulis dan menggunakan rumus, sehingga meningkat sebesar $8,88 \%$.

3. Aktivitas siswa untuk menggambar bangun geometri pada siklus I sebesar 70,00 \% karena biasanya siswa hanya melihat gambar di buku,atau melihat gurunya menggambar di papan tulis, pada siklus II sebesar 76,67 \% karena siswa sudah mulai berusaha untuk menggambar bangun geometri, sehingga meningkat sebesar $6,67 \%$.

4. Aktivitas siswa untuk bertanya atau menjawab pertanyaan pada siklus I sebesar 21,11 \% karena siswa terbiasa menerima informasi secara verbal dari guru, pada siklus II sebesar 32,22 \% karena siswa sudah mulai berani bertanya tentang materi yang belum dipahaminya atau menjawab pertanyaan siswa lain dan siswa sudah mulai berani untuk mengungkapkan pendapatnya, sehingga meningkat sebesar $11,11 \%$.

5. Aktivitas siswa untuk mengerjakan soal-soal latihan pada siklus I sebesar 81,11 \% karena siswa terbiasa menunggu jawaban dari guru, pada siklus II sebesar 91,11 $\%$ karena siswa sudah mulai mencari jawaban sendiri, sehingga meningkat sebesar $10,00 \%$. 
Secara keseluruhan rata-rata persentase aktivitas belajar siswa dari siklus I ke siklus II meningkat.
Dari tes tertulis pada siklus I dan siklus II sebelum remidi diperoleh hasil belajar siswa sebagai berikut :

Tabel 3. Rekapitulasi Hasil Evaluasi Siklus I dan Siklus II

\begin{tabular}{|c|c|c|c|}
\hline Rentang Nilai & Keterangan & Siklus I & Siklus II \\
\hline$<60$ & Belum tuntas & $46,7 \%$ & $30,0 \%$ \\
\hline$\geq 60$ & Tuntas & $53,3 \%$ & $70,0 \%$ \\
\hline Jumlah & - & $100 \%$ & $100 \%$ \\
\hline
\end{tabular}

Berdasarkan Tabel 3. di atas diperoleh:

Sebelum remidi pada siklus I hasil belajar siswa yang mendapat nilai $<60$ adalah 46,7 \%, dan yang mendapat nilai $\geq 60$ adalah 53,3 \%, sedangkan pada siklus II yang mendapatkan nilai < 60 adalah 30,0 \% dan yang mendapat nilai $\geq 60$ adalah $70,0 \%$. Hal ini menunjukkan bahwa hasil belajar siswa siklus II meningkat $16,7 \%$ dari hasil belajar pada siklus I.

Dengan demikian sesuai dengan harapan peneliti, dengan menggunakan CD Pembelajaran dapat meningkatkan aktivitas belajar siswa dan hasil belajar siswa. Walaupun pada siklus I siswa yang belum tuntas belajar masih 46,7 \% dan yang tuntas belajar baru 53,3 \%, tetapi setelah peneliti melakukan tindakan perbaikan proses pembelajaran pada siklus II siswa yang belum tuntas belajar hanya tinggal 30,0\% dan yang tuntas belajar mencapai 70,0\%.

\section{KESIMPULAN DAN SARAN}

\section{Berdasarkan hasil analisis, diperoleh rata-rata aktivitas siswa sebelum tindakan sebesar $42,53 \%$, rata- rata aktivitas siswa siklus I sebesar $65,33 \%$ dan rata-rata aktivitas siswa siklus II $74,00 \%$. Berarti rata-rata aktivitas siswa mengalami peningkatan $15,7 \%$. Rata-rata hasil belajar siswa siklus I sebesar 56,7 dan rata-rata hasil belajar siswa siklus II sebesar 65,3}

berarti rata-rata hasil belajar meningkat $15,2 \%$. Sebelum remidi banyak siswa yang tuntas belajar pada siklus I sebanyak 16 orang siswa $(53,3 \%)$, hal ini mengalami peningkatan 5 orang siswa $(16,7 \%)$ dari sebelum tindakan. Dan pada siklus II siswa yang tuntas belajar sebanyak 21 orang siswa(70,0\%), hal ini mengalami peningkatan 5 orang siswa $(16,7 \%)$ dari siklus I.

Berdasarkan hasil penelitian tindakan kelas dilakukan dan pembahasan yang telah diuraikan, maka dapat disimpulkan bahwa penggunaan CD Pembelajaran pada pembelajaran Matematika materi segitiga dan segiempat dapat meningkatkan aktivitas dan hasil belajar siswa kelas VII.1 SMPN 1 Banjar Margo, Kabupaten Tulang Bawang Tahun Pelajaran 2015/2016.

Saran bagi guru setelah penelitian ini adalah agar dapat penggunaan CD Pembelajaran pada pembelajaran matematika guna meningkatkan kualitas pembelajaran. Selanjutnya, bagi guru atau para peneliti dapat melakukan penelitian lanjutan untuk mengetahui peningkatan kemampuan siswa pada berpikir pada tingkat tinggi.

\section{DAFTAR PUSTAKA}


e-ISSN 2442-5419 Vol. 5, No. 2 (2016) 180-186

p-ISSN 2089-8703

Ahmadi, A. 2001. Ilmu Pendidikan. Jakarta: PT. Rineka Cipta.

Arikunto, S. 2006. Prosedur Penelitian Suatu Pendekatan Praktek. Jakarta: PT. Rineka Cipta.

Hamalik, O. 2003. Proses Belajar Mengajar. Jakarta: PT. Bumi Aksara

Sanjaya, W. 2006. Strategi Pembelajaran. Jakarta: Kencana Prenada Media Group

Sardiman, A. M. 2007. Interaksi dan Motivasi Belajar Mengajar: Bandung, Rajawali Pers 